\title{
HOT-WATER DRILLING IN THE ANTARCTIC PENINSULA
}

\section{(Abstract)}

\author{
by
}

S. Cooper

(British Antarctic Survey, Natural Environment Research Council, High Cross, Madingley Road, Cambridge CB3 OET, England)

\section{ABSTRACT}

The British Antarctic Survey has developed a hot-water drilling system used chiefly for installing temperature sensors through ice shelves and for retrieving oceanographic equipment tethered through thick fast ice. The specification, design and operation of the drill for these two activities will be discussed and practical field problems will be highlighted.

A novel aspect of the design is the use of reaming nozzles to enlarge a pilot hole. These nozzles eject water upwards along the surface of the nozzle cone, and drill most efficiently when they hang free and unsupported by the sides of the pilot hole. The nozzles incorporate a nozzle-mounted valve, activated when the nozzle cone contacts the ice, thus increasing the back pressure of the water flow. The pressure increase is monitored at the surface and the winch speed is reduced accordingly in order to ensure an efficient drilling operation.

\section{DISTRIBUTION OF SURFACE FEATURES AND SURFACE MASS BALANCE OF ICE SHEET, EAST QUEEN MAUD LAND, ANTARCTICA \\ (Abstract)}

by

Yoshiyuki Fujii

(National Institute of Polar Research, 9-10, Kaga 1-chome, Itabashi-ku, Tokyo 173, Japan)

and

Yukata Ageta

(Water Research Institute, Nagoya University, Furo-cho, Chikusa-ku, Nagoya 464, Japan)

\section{ABSTRACT}

Surface features were classified morphologically and described along oversnow traverse routes from the coast to the inland high plateau of east Queen Maud Land, Antarctica, during the 1984 and 1985 summer seasons. The distribution of surface features reveals regional characteristics which reflect differences in the regional deposition-erosion process.

On the basis of observation of surface features and measurements of surface mass balance, the ice-sheet surface of east Queen Maud Land is sub-divided according to different environmental zones:

(1) Ablation zone (below $700 \mathrm{~m}$ a.s.1.): melting of snow occurs. Dry snow line approximates the altitude where the maximum air temperature is $0^{\circ} \mathrm{C}$.

(2) Coastal continuous accumulation zone (700-1800 m a.s.1.): snow accumulation occurs continuously and the surface is flat because of high snow precipitation and a slight katabatic wind.
(3) Discontinuous accumulation zone (1800-2500 m a.s.1.): a rough surface of sastrugi dominates this zone. Snow accumulation is discontinuous in space and time because of low snow precipitation and strong katabatic wind. Negative annual snow accumulation was observed at $20-30 \%$ of the stakes set every $2 \mathrm{~km}$ along the traverse route. Mizuho Station is located in this zone.

(4) Long-term accumulation-free zone (2500-3400 m a.s.l.): long-term absence of snow accumulation occurs at the glazed surface, which consists of a multi-layered ice crust several millimetres thick. A glazed surface develops over a distance of $1-20 \mathrm{~km}$ when the surface undulation is steeper, and covers $30-50 \%$ of the area in this zone. A hiatus sequence of snow accumulation is thought to continue for about -10-100 years over the glazed surface region.

(5) Inland continuous accumulation zone (above $3400 \mathrm{~m}$ a.s.1.): a flat surface dominates in this zone. Snow accumulation occurs continuously because there is a weak katabatic wind in the central high plateau in spite of a very small amount of precipitation. 